\title{
Potensi Infografik dalam Menangani Persepsi Negatif Netizen Terhadap Institusi Zakat di Malaysia
}

\author{
ALIFF NAWI \\ MOHD ZAILANI MOHD YUSOFF \\ Universiti Utara Malaysia \\ CHUA CHY REN \\ Albukhary International University, Malaysia \\ AHMAD SAHIDAH \\ Universitas Nurul Jadid, Indonesia
}

\begin{abstract}
ABSTRAK
Di Malaysia, antara perkara yang sering menjadi viral atau perbualan netizan adalah berkaitan dengan pelbagai ketidakpuasan masyarakat terhadap institusi zakat. Ketidakpuasan masyarakat ini merangkumi tahap kepuasan agihan, kualiti perkhidmatan, sikap pengguna dan kepercayaan terhadap institusi zakat. Oleh yang demikian, tujuan artikel ini adalah untuk meneroka potensi penggunaan infografik sebagai medium penyampai maklumat yang efektif dalam menjawab persoalan, menangani isu dan masalah yang dilontarkan oleh netizen. Kajian ini dijalankan secara kualitatif melalui pemerhatian terhadap media sosial dan laman sesawang institusi-institusi zakat di Malaysia dalam memaparkan maklumat tentang usaha dan inisiatif mereka dalam membasmi kemiskinan. Selain itu, analisis kandungan juga dilakukan dengan menggunakan kaedah PRISMA untuk mengenal pasti keberkesanan penggunaan infografik dalam menyampaikan maklumat. Hasil dapatan pemerhatian menunjukkan bahawa penglibatan institusi zakat dalam media sosial berada di peringkat awal dan belum digunakan secara maksimum. Dapatan analisis kandungan pula menunjukkan bahawa penggunaan infografik berkesan dari aspek penyampaian maklumat terutamanya melibatkan maklumat yang banyak dan kompleks serta membantu semua lapisan masyarakat dalam mengingati fakta. Pemilihan kombinasi warna dalam infografik turut berperanan dalam menarik perhatian pengguna dan memaparkan maklumat yang pelbagai. Terdapat beberapa cadangan turut dibincangkan untuk menggunakan infografik sebagai medium penyampai maklumat yang efektif dalam menangani isu dan tanggapan negatif dari netizen.
\end{abstract}

Kata kunci: Infografik, netizen, institusi, zakat, Malaysia.

\section{Utilizations of Infographics for Dissatisfied Netizens towards Zakat Institutions in Malaysia}

\begin{abstract}
Resentment towards zakat institutions in Malaysia is viral issues among netizens. Netizens' dissatisfaction towards the institutions includes proportions of zakat distribution, service quality, consumer attitude and trust in the institution. Therefore, this paper aims to explore the potentials of infographics as an effective communication tool to provide accurate information and to address issues and concerns raised by the netizens. This study was qualitatively conducted via observation checklists on the institutions' social media platforms as part of their initiatives to eradicate poverty. This study
\end{abstract}


employed the PRISMA (Preferred Reporting Items Systematic Reviews and Meta-Analysis) method to determine the effectiveness of infographics in communicating and delivering the intended information. The findings showed that the institutions' participation in social media was still at an infant stage and has not been fully utilized. Nevertheless, the use of infographics was successful in presenting details, particularly broad and complicated ones and, in assisting users to retain facts. In terms of colour combination options in the infographics, it has played essential roles in attracting users and presenting a wide range of information. Subsequently, several recommendations on the use of infographics as a valuable tool of communication are put forth in addressing the netizens' issues and concerns towards zakat institutions in Malaysia.

Keywords: Infographic, netizen, institution, zakat, Malaysia.

\section{PENGENALAN}

Infografik berasal dari ungkapan dua perkataan asal bahasa Inggeris iaitu information (maklumat) dan graphic (grafik). Menurut Kamus English Oxford, gabungan perkataan infografik membawa maksud gambaran persembahan tentang sesuatu informasi atau data. Melalui infografik, maklumat atau data yang kompleks dapat dipaparkan melalui satu bentuk visual dengan menggabungkan unsur-unsur seperti bentuk, simbol, grafik, gambar, ilustrasi dan teks (Ozdamli \& Omdal, 2018). Maklumat yang dipaparkan menerusi infografik juga dapat dipersembahkan kepada pembaca dengan cepat dan mudah agar difahami dengan baik.

Selain itu, infografik hanya menggunakan teks secara minimum atau simbol yang pendek dan ringkas. la berfungsi sebagai alat komunikasi visual dalam kehidupan sosial manusia. Penggunaan ini termasuklah seperti objek yang dipaparkan pada papan tanda yang terdapat di jalan raya, peta, pendidikan, penulisan teknikal dan sebagainya. Infografik turut mempunyai identitinya yang tersendiri dan unik. Sebagai contoh, isi kandungan dalam infografik terdiri daripada beberapa jumlah maklumat yang optimum, disusun atur dengan baik dan kombinasi warna yang menarik dan sesuai dengan keadaan berdasarkan prinsip reka bentuk berarahan (instructional design principles).

Di samping itu, penggunaan infografik di internet dapat disebarkan dengan lebih pantas berbanding dengan maklumat atau kandungan yang bercetak. Penggunaan infografik turut mempunyai reka bentuk infografik yang jelas, menarik dan ringkas, mudah dilihat, difahami, menguntungkan laman internet dan mudah untuk dikongsikan kepada umum tanpa mengira sempadan. Malah, penyampaian menerusi infografik lebih mudah difahami kerana otak manusia berdasarkan hasil penyelidikan didapati mampu memproses data visual lebih pantas 60000 kali berbanding teks. Malah, Bradford (2004) menyatakan bahawa golongan penyampai yang bergantung kepada teks jauh lebih lambat daripada golongan penyampai yang bergantung kepada bantuan visual iaitu $43 \%$ lebih berkesan untuk meyakinkan para pembaca atau penonton.

Infografik semakin mendapat perhatian dalam khalayak manusia pada setiap peringkat terutamanya di media sosial seperti Twitter, Facebook, Instagram, blog, laman sesawang, WhatsApp, Telegram, Line dan sebagainya. Penggunaan infografik dilihat semakin diminati berpunca daripada ciri-ciri persembahan teksnya yang menarik, ringkas dan mudah dibaca dan sifatnya yang bermaklumat (informative) dan mempunyai elemen memujuk (persuasive) (Piotti \& Murphy, 2019). Elemen informasi dan pujukan diterapkan dalam infografik agar dapat memberi keyakinan kepada pembaca dan menyedarkan mereka untuk bertindak melakukan perbuatan baik seperti perubahan sikap positif dalam diri dan sikap membantu orang lain. 


\section{PERNYATAAN MASALAH}

Perkembangan dalam bidang teknologi maklumat dan komunikasi menjadikan dunia kini tanpa sempadan. Lebih-lebih lagi dengan kewujudan media sosial seperti Twitter, Facebook, Instagram dan WhatsApp memberi kesan baharu kepada pengguna untuk lebih aktif berinteraksi di dalam talian. Kecenderungan manusia untuk berada dalam persekitaran digital menjadi pilihan terutamanya dalam kalangan remaja. Media sosial menjadi platform utama untuk para remaja meluangkan masa untuk bersosial dan berkomunikasi antara satu sama lain (Hashim \& Razali, 2019). Kajian X-Ophir, Asterhan dan Schwarz (2018) menunjukkan bahawa media sosial juga turut digunakan untuk meluahkan perasaan, berkongsi pandangan dan melepaskan emosi di dalam diri.

Bagaimanapun, ramai pengguna tidak mengambil berat terhadap etika dalam media sosial. Ramai pengguna lebih suka untuk post, like dan share berita yang tidak diketahui kesahihannya (Vosoughi et al., 2018). Menurut Judith et al. (2018), berita palsu boleh mengelirukan pengguna dan menjejaskan pelbagai pihak. Antaranya seperti pengakuan tidak benar, maklumat palsu serangan pengganas, berita bencana alam dan sebagainya. Akibatnya, berita palsu ini boleh menjejaskan kredibiliti sesebuah syarikat atau institusi, menghilangkan kepercayaan terhadap sesuatu pihak dan mempengaruhi pemikiran masyarakat untuk mengundi dalam sesebuah pilihanraya.

Di Malaysia, antara berita yang sering tular dalam kalangan netizen di media sosial adalah berkaitan dengan ketidakpuasan masyarakat terhadap institusi zakat. Antara perkara yang menjadi perbualan netizen berkaitan dengan tahap kepuasan agihan, kualiti perkhidmatan, sikap pengguna dan kepercayaan terhadap institusi zakat (Maryam et al., 2018). Bahkan, tinjauan ringkas oleh Astro Awani pada tahun 2016 mendapati majoriti netizen (70\%) lebih sanggup membayar zakat terus kepada asnaf berbanding kepada institusi zakat. Kajian Hafizah (2017) turut menegaskan bahawa faktor kepercayaan dan keyakinan merupakan elemen yang paling dominan menjadi penentu terhadap pandangan mereka sama ada baik atau pun buruk terhadap institusi zakat. Hal ini menjelaskan bahawa masyarakat tidak yakin dan tidak percaya terhadap institusi zakat dalam melaksanakan tanggungjawab yang diamanahkan.

Selain itu, terdapat banyak kajian turut membuktikan bahawa masyarakat memandang sinis terhadap institusi zakat. Antara isu yang sering diperkatakan oleh masyarakat tentang pengurusan institusi zakat yang digambarkan tidak efektif, pengagihan bantuan secara tidak cekap dan gagal dalam membantu masyarakat (Hairunnizam et al., 2009; Ezza Ellany et al., 2014). Senario ini dikhuatiri dapat memberi impak yang negatif kepada institusi zakat malahan dapat menjatuhkan imej institusi zakat sebagai pemegang amanah. Oleh yang demikian, keperluan untuk membangunkan infografik adalah bertepatan bagi meningkatkan lagi keberkesanan penyampaian dan menyebarluaskan maklumat tentang usaha dan inisiatif institusi zakat dalam membantu lapisan masyarakat.

\section{TINJAUAN LITERATUR}

Sejarah kemunculan infografik bermula sejak 3000BC di Zaman Tamadun Mesir Purba. Pada masa itu, sistem penulisan yang dipanggil sebagai Hieroglif Mesir menggunakan simbol untuk menggambarkan perkataan, huruf dan konsep terutamanya menggambarkan kehidupan, kerja, dan agama (Krystian, 2016). Selain itu, penemuan lakaran lukisan di atas batu yang terdapat di dalam Gua Lascaux (Montignac, Dordogne, Perancis) yang berusia sekitar 17,000 
tahun dan dipercayai sejak Zaman Paleolitik (Gittins \& Pettitt, 2017) turut membuktikan bahawa infografik telah lama digunakan sebelum ini.

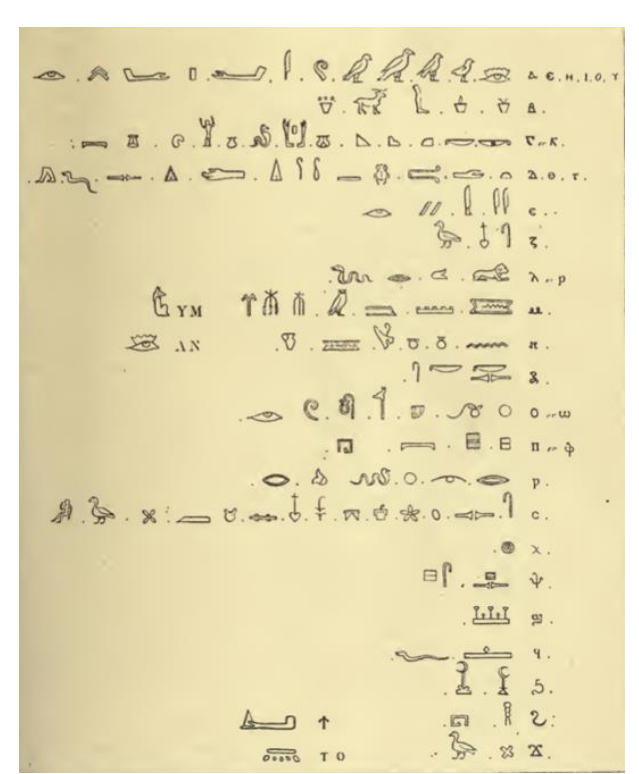

Tulisan Hieroglif Mesir yang dilakarkan di dalam kamus terjemahan oleh Budge (1920).

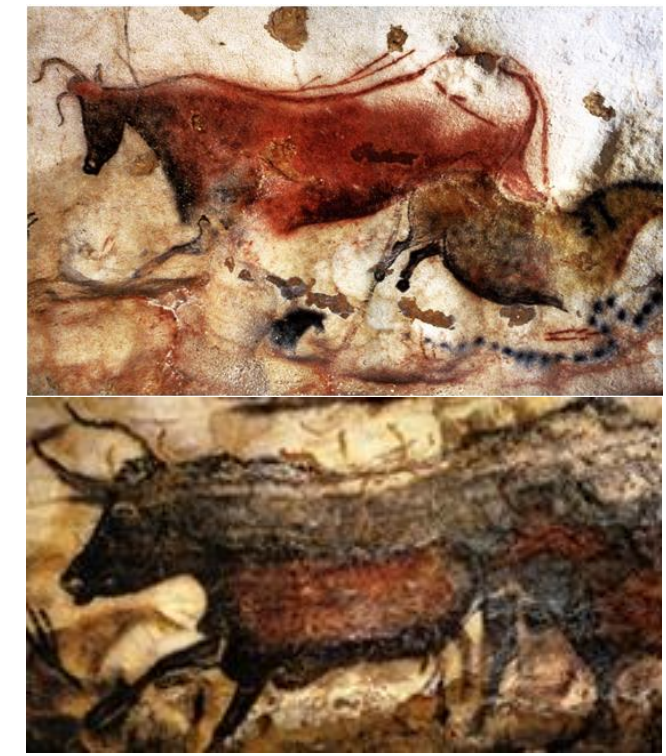

Lukisan berusia hampir 30,000 tahun ditemui di Gua Lascaux di Perancis. Gambar oleh Aujoulat (2005)

Rajah 1: Contoh infografik pada zaman dahulu

Pada abad ke-18, penggunaan infografik mula diperkenalkan kembali oleh William Playfair yang berasal dari Scotland. Beliau dianggap sebagai bapa grafik statistik kerana mencipta carta bar, carta pai dan barisan yang sering digunakan sehingga ke hari ini. Menurut Costigan-Eaves dan Macdonald-Ross (1990), Atlas Komersial dan Politik merupakan hasil karya yang paling unggul dihasilkan beliau pada tahun 1786 semasa bekerja sebagai usahawan dan ahli ekonomi. Selain itu, beliau mempunyai kemahiran yang luar biasa dalam menghubungkan grafik dengan keperluan psikologi pembaca.

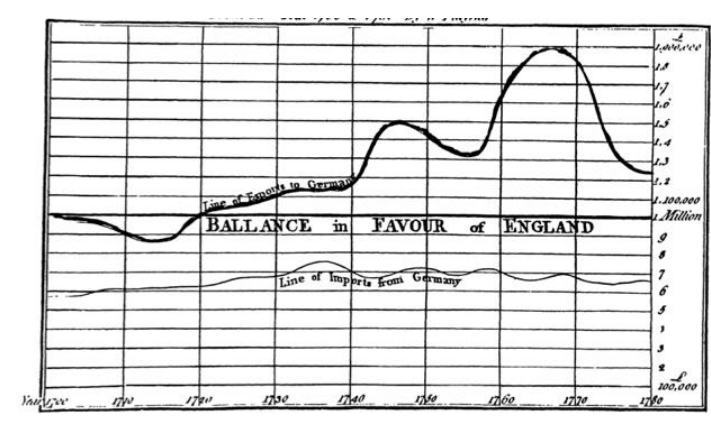

Pada tahun 1786, Playfair merangka lengkungan tebal untuk mendapatkan tumpuan pembaca. Gambar oleh Costigan-Eaves dan Macdonald-Ross (1990).

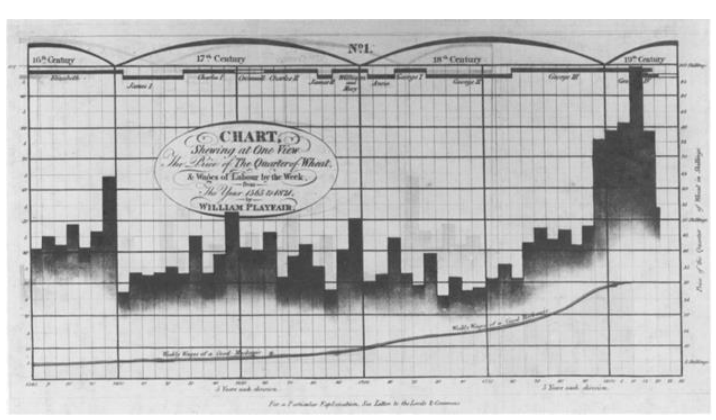

Salah satu grafik berwarna yang dihasilkan oleh Playfair pada tahun 1820 yang memaparkan ketidakadilan harga gandum dengan upah buruh.

Rajah 2: Infografik berbentuk carta bar

Carta pai kemudiannya diberi nafas baru pada abad yang ke-18. Florence Nightingale, seorang jururawat yang bertugas di hospital semasa berlakunya peperangan Krimean di Eropah. Beliau menyedari bahawa ramai askar yang tercedera tidak dapat diselamatkan 
akibat dari kegagalan untuk mengawal kebersihan (Mackey \& Bassendowski, 2017). Ekoran dari itu, beliau cuba melaporkan data pesakit dan kadar kematian dalam bentuk rajah (Meyers \& McNicholas, 2008). Hasilnya, rajah ini akhirnya dapat menarik perhatian pihak berwajib untuk meningkatkan fasiliti hospital dan berjaya menyelamatkan ramai nyawa tentera.

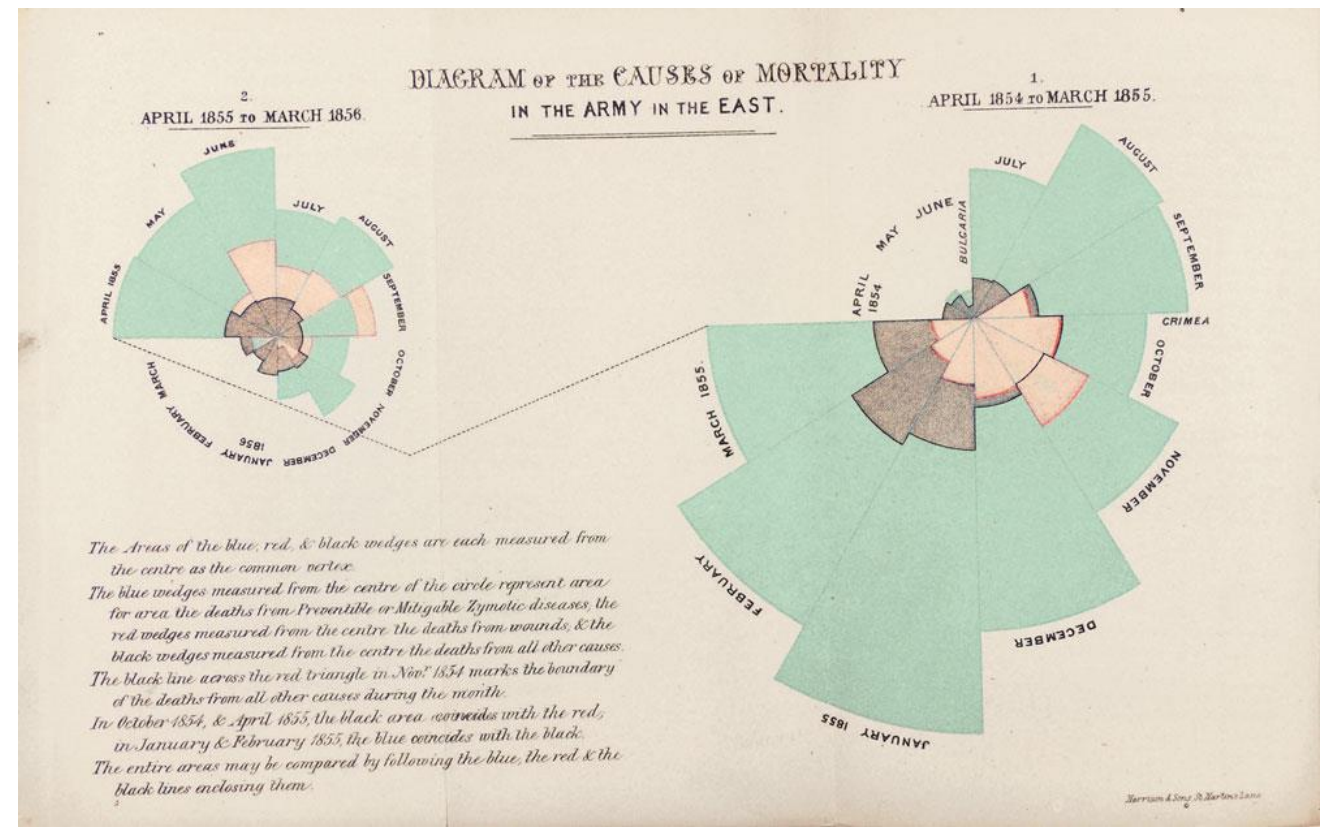

Rajah 3: Infografik berbentuk diagram

Nota: Diagram berwarna seperti bunga rose divisualkan oleh Florence Nightingale pada tahun 1858 memaparkan statistik bilangan tentera yang mati di hospital. Warna hijau (asalnya berwarna biru sebelum pudar) di dalam diagram mewakili bilangan tentera yang mati akibat dari penyakit yang boleh dicegah (kolera dan typhus), warna krim (asalnya berwarna merah sebelum pudar) mewakili bilangan tentera yang mati akibat luka parah dan warna perang (asalnya berwarna hitam) mewakili bilangan tentera yang mati oleh sebab-sebab lain.

Pada abad ke-20, Harry Beck buat pertama kalinya dalam sejarah telah mencipta infografik berbentuk kartografi yang menghubungkan kesemua pengangkutan awam di kawasan utama di England. Kesemua mercu tanda masyhur dan nama-nama stesen yang dimasukkan ke dalam peta menjadikan pembaca lebih mudah untuk meneroka kawasan sekitar. Menurut Field dan Cartwright (2014), peta yang dihasilkan mempunyai kehalusan seni yang baik dan simbol yang digunakan amat jelas serta mempunyai komposisi objek yang tersusun atur sehingga dapat digunakan dalam 80 tahun lamanya sebelum ditukar kepada peta yang baru. Peta tersebut berjaya menjadi lambang geografi London dan menjelaskan secara mudah bagaimana pengangkutan awam di London berfungsi. 


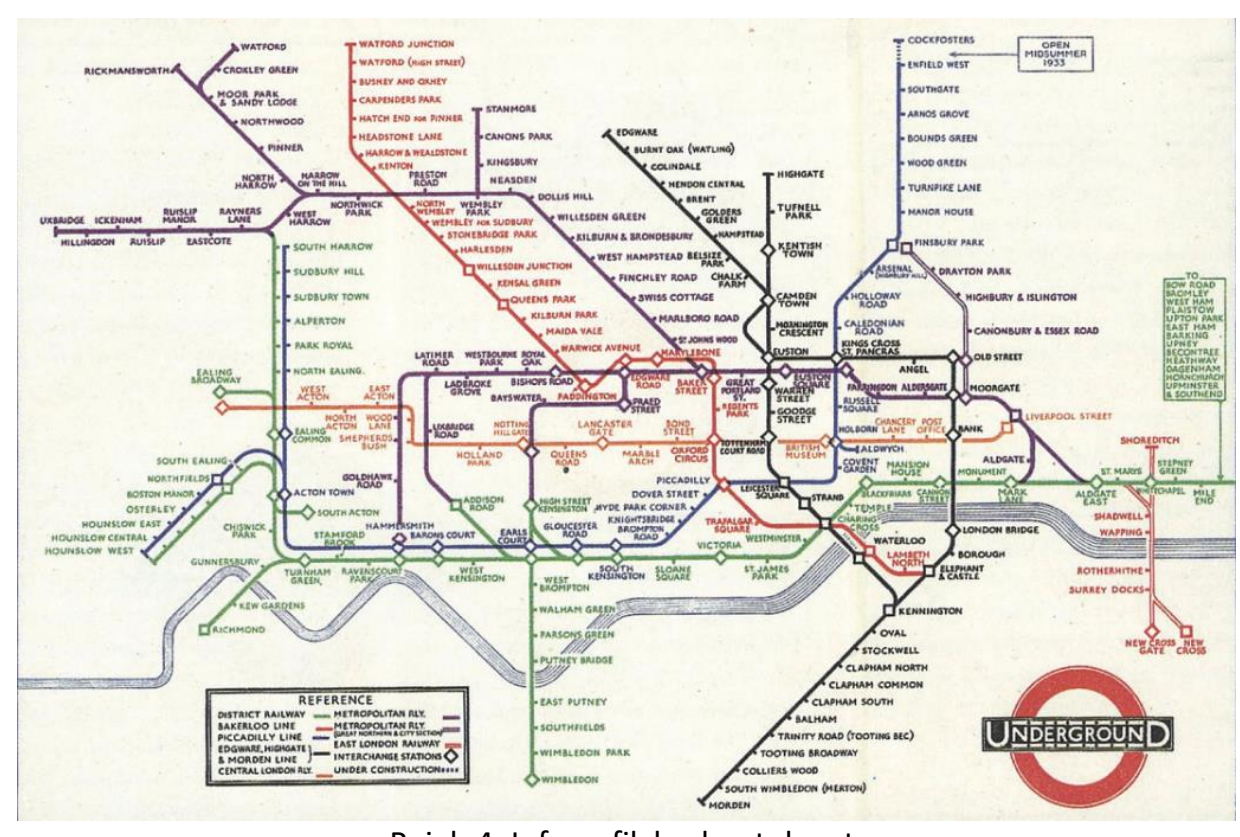

Rajah 4: Infografik berbentuk peta

Nota: Idea Beck (1933) memberi sumbangan besar dalam menghasilkan reka bentuk peta yang melibatkan kesemua pengangkutan awam termasuklah subway, metro dan pengangkutan awam yang lain.

Sementara di German, Otl Aicher menghasilkan infografik yang dikenali sebagai pictograms untuk Sukan Olimpik di Munich. Pictogram yang direka beliau pada tahun 1972 merupakan perintis bagi grafik abad ke-20 yang memaparkan simbol manusia yang beraksi dalam sukan (Holmes, 2000). Beliau juga mencipta banyak logo visual dan poster untuk pelbagai jenis syarikat (Schiller \& Young, 2010). Simbol yang digunakan oleh Aicher menjadi amat terkenal dan digunakan secara meluas serta mempengaruhi reka bentuk grafik yang digunakan pada hari ini.

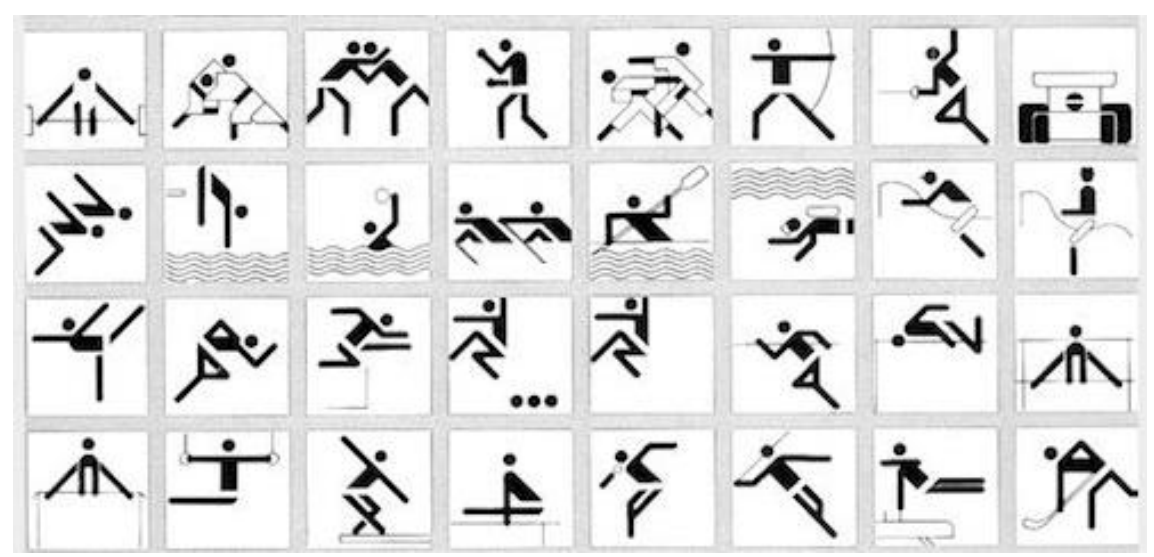

Rajah 5: Infografik berbentuk pictograms

Nota: Antara simbol yang dicipta oleh Otl Aicher pada tahun 1972 untuk Sukan Olimpik di German (Rathgeb, 2015).

Pada abad yang sama, Edward Tufte mula mengembangkan penggunaan infografik dengan mengintegrasikan pelbagai data. Menurut Yuvaraj (2017), Tufte bersama rakannya, John Tukey bekerjasama menganjurkan bengkel, seminar dan kuliah berkaitan dengan infografik dan statistik. Kedua-duanya turut terkenal sebagai perintis data visual dan perintis reka bentuk teknologi maklumat. Tufte pada masa itu merupakan pensyarah di Princeton 
University di New Jersey mula giat untuk memperkenalkan data visual kepada umum sehingga digunakan secara meluas.

Pada akhir abad ke-20, penggunaan infografik mula mendapat tempat dalam kalangan pengguna komputer. Kemunculan perisian Microsoft Office pada tahun 1988 memudahkan penghasilan pelbagai jenis grafik seperti grafik yang bergerak, grafik interaktif dan sebagainya (Yuvaraj, 2017). Setelah memasuki awal abad ke-21, infografik yang pada awalnya berbentuk cetakan telah berubah ke dalam bentuk digital dan terus mengalami perubahan sehingga ke platform berbentuk dalam talian, sehingga ke hari ini.

Berdasarkan kepada perkembangan dan inovasi dalam infografik, maka kajian ini bertujuan untuk membincangkan tentang potensi penggunaan infografik sebagai medium penyampai maklumat efektif dalam memaparkan maklumat tentang usaha dan inisiatif membasmi kemiskinan. Penggunaan infografik juga dilihat sebagai berpotensi untuk mempengaruhi dan mengubah persepsi netizen khususnya dalam menangani isu dan masalah yang dilontarkan dalam talian.

\section{METODOLOGI}

Kajian ini dijalankan secara kualitatif menerusi kaedah pemerhatian dan analisis kandungan. Bagi kaedah pemerhatian, semua media sosial dan laman sesawang yang digunakan oleh institusi-institusi zakat di seluruh Malaysia termasuklah Perlis, Kedah, Pulau Pinang, Perak, Kelantan, Terengganu, Negeri Sembilan, Kuala Lumpur, Melaka, Sabah dan Sarawak terlibat dalam pemerhatian. Pemerhatian ini dilakukan menerusi senarai semak yang mengambil kira maklumat usaha dan inisiatif yang dipaparkan secara dalam talian.

Manakala analisis kandungan pula dijalankan dengan menggunakan kaedah PRISMA. PRISMA atau Preferred Reporting Items Systematic Reviews and Meta-Analysis merupakan satu proses tinjauan secara sistematik yang merangkumi prosedur dan kriteria kelayakan tertentu untuk mendapatkan pelbagai maklumat dalam penyelidikan (Sierra-Correa \& Kintz, 2015). Dalam kajian ini, terdapat empat tahap kriteria kelayakan dan pengecualian ditentukan. Pertama, hanya artikel jurnal yang dipilih. Kedua, untuk mengelakkan kekeliruan dan kesukaran dalam terjemahan, hanya artikel dalam bahasa Inggeris diambil kira. Ketiga, pemilihan artikel hanya dalam jangka masa sepuluh tahun (antara 2009 hingga 2019) yang merupakan jangka masa yang mencukupi untuk melihat trend penyelidikan dan penerbitan yang berkaitan. Keempat, hanya artikel yang berbentuk kajian dipilih untuk diambil kira dalam analisis kandungan ini.

Proses analisis kandungan bermula pada Disember 2019 dengan menggunakan kata kunci carian "TITLE-ABS-KEY (( infographi* ) AND ( educat* )). Pada awalnya, pangkalan Scopus memaparkan 81 artikel yang menggunakan kata kunci yang sama dalam carian. Namun, setelah proses semakan dan kelayakan, hanya 29 artikel yang diambilkira dalam analisis kandungan ini. Data diekstrak dengan membuat pembacaan pada bahagian abstrak terlebih dahulu, diikuti dengan keseluruhan artikel secara mendalam. Proses ini dilaksanakan bagi mengenalpasti tema dan sub tema yang bersesuaian.

\section{DAPATAN}

Pemerhatian Terhadap Media Sosial dan Laman Sesawang Institusi Zakat dalam Media Sosial Menurut laporan digital global dari sebuah agensi data dunia, Facebook merupakan media sosial yang paling tinggi kadar penggunaannya dalam kalangan netizen di Malaysia, diikuti dengan YouTube, Instagram dan lain-lain. Manakala, WhatsApp pula merupakan aplikasi 
mobile yang paling tinggi kadar penggunaannya berbanding Facebook, Instagram, WeChat, Waze, Lazada, Grab dan lain-lain (We are social, 2019). Melalui statistik pengguna ini juga, didapati bahawa pengguna media sosial meningkat setiap tahun. Pengguna turut cenderung menggunakan aplikasi media sosial melalui bahan yang mudah alih seperti telefon pintar.

Jika dilihat kepada penglibatan institusi zakat dalam media sosial (Jadual 1), di dapati bahawa hampir kesemua institusi zakat telah pun menggunakan platform media sosial untuk berinteraksi secara digital dengan masyarakat. Walaupun jumlah follower pengguna adalah berbeza setiap negeri, namun perkara ini menunjukkan bahawa netizen sedar akan kewujudan dan penglibatan institusi zakat dalam media sosial. Jumlah pengguna yang menjadi follower atau like ini merupakan pengguna yang bakal mendapat maklumat secara langsung dari sesebuah organisasi. Setiap post yang diberikan juga akan mendapat maklum balas dari pembaca seperti like, sharing, comment atau hanya melihat sepintas lalu sahaja.

Jadual 1: Penglibatan Institusi Zakat dalam Media Sosial

\begin{tabular}{|c|c|c|c|c|c|}
\hline \multirow[t]{2}{*}{ Negeri } & \multicolumn{5}{|c|}{ Media Sosial } \\
\hline & $\begin{array}{l}\text { Facebook } \\
\text { Liker* }\end{array}$ & $\begin{array}{c}\text { YouTube } \\
\text { Subscribers* }\end{array}$ & Whatsapp & Instagram Follower* & $\begin{array}{c}\text { Twitter } \\
\text { Follower* }\end{array}$ \\
\hline Kuala & PPZ & PPZTV & - & @pusatpungutanzakat & $@ p p z w p$ \\
\hline Lumpur & 155,837 & 2,640 & & 4,487 & 2,316 \\
\hline \multirow[t]{2}{*}{ Selangor } & LZS & ZSTV & - & @zakatselangor & @zakatselangor \\
\hline & 251,170 & 1,285 & & 15,900 & 1,771 \\
\hline Negeri & MAINS & PZNS & - & - & - \\
\hline Sembilan & 35,976 & 57 & & & \\
\hline \multirow[t]{2}{*}{ Melaka } & ZM & MTV & & @zakatmelaka & @maim_melaka \\
\hline & 6,609 & 2,874 & & 72 & 52 \\
\hline \multirow[t]{2}{*}{ Johor } & MAIJ & - & & @mainj_official & - \\
\hline & 12,309 & & & 1,371 & \\
\hline \multirow[t]{2}{*}{ Perak } & ZP & - & - & @zakatperakmaipk & @zakat_perak \\
\hline & 13,415 & & & 802 & 24 \\
\hline \multirow[t]{2}{*}{ Pulau Pinang } & ZPP & $\mathrm{ZP}$ & & @zakatpenang & @zakatpenang \\
\hline & 17,763 & 100 & & 2,009 & 4 \\
\hline \multirow[t]{2}{*}{ Kedah } & LZNKDA & ZK & $\checkmark$ & @zakatkedah & @zakatkedah \\
\hline & 43,833 & 195 & & 1,698 & 605 \\
\hline \multirow[t]{2}{*}{ Perlis } & MAIPs & - & - & - & - \\
\hline & 9,236 & & & & \\
\hline \multirow[t]{2}{*}{ Pahang } & PKZP & ZPTV & & @zakatpahang & @zakatpahang \\
\hline & 38,437 & 358 & & 2,240 & 221 \\
\hline \multirow[t]{2}{*}{ Terengganu } & MAIDAM & MAIDAMT & - & - & - \\
\hline & 11,358 & 60 & & & \\
\hline \multirow[t]{2}{*}{ Kelantan } & MAIK & MAIK & & @maikkelantann & @maik \\
\hline & 5,134 & 1,219 & & 1,934 & 169 \\
\hline \multirow[t]{2}{*}{ Sabah } & BZFMUIS & ZSMUIS & & @zakatsabah & @bzdmuis \\
\hline & 14,401 & 1 & & 14 & 262 \\
\hline \multirow[t]{2}{*}{ Sarawak } & TBS & - & - & - & @baitulmalswk \\
\hline & 11,332 & & & & 36 \\
\hline
\end{tabular}

*Data dikemaskini pada 17 Jun 2019

Sebenarnya, tindakan pembaca seperti like, sharing atau comment dalam media sosial membawa maksud yang tersirat. Pembaca kebiasaannya akan cenderung untuk like status yang bergambar dan memberi komen pada status yang meminta maklum balas atau bermaklumat. Manakala status bergambar atau video yang mempunyai unsur nilai-nilai murni akan dikongsi oleh pembaca. Sebaliknya, post yang mempunyai nilai negatif atau membangga 
diri akan diabaikan oleh pembaca (Kim \& Yang, 2017; Rush \& Cameron, 2016). Hal ini menunjukkan bahawa tingkah laku pengguna dalam dunia digital merupakan cerminan untuk mengetahui sama ada sesuatu mesej yang disampaikan itu berkesan atau tidak.

Dari perspektif psikologi, aktiviti dalam media sosial (like, post, sharing dan comment) merupakan gambaran atau luahan emosi secara virtual (Carrier et al., 2015). lanya memberi impak kepada pembaca terutamanya apabila 'status' berkenaan mempunyai perkaitan langsung dengan pembaca dalam kehidupan sebenar. Salah satu contoh 'status' impak terhadap pembaca apabila ianya menjadi viral dalam sesebuah komuniti. Melalui pemerhatian Berger (2014), terdapat enam ciri status yang berpotensi menjadikan sesuatu 'status' tersebut viral, iaitu; 1) perkongsian bermaklumat; 2) mempunyai unsur tarikan kekal; 3) menyentuh emosi; 4) membawa nilai peribadi bersama; 5) nilai yang praktikal; 6) berkaitan isu semasa. Status yang viral mempunyai potensi untuk memberi tarikan, kesedaran dan perubahan terhadap tingkah laku dalam sesebuah kumpulan (Alhabash et al., 2018).

\section{Pemerhatian dari Laman Sesawang Institusi-Institusi Zakat di Malaysia}

Berdasarkan kepada pemerhatian dalam laman sesawang institusi-institusi zakat yang dipaparkan, terdapat pelbagai usaha dan inisiatif oleh institusi zakat dalam membantu masyarakat tempatan. Kakitangan pusat zakat juga berusaha siang dan malam menggembleng tenaga untuk membantu penduduk tempatan tanpa mengira masa. Terdapat juga pelbagai bantuan yang telah diperuntukkan kepada penduduk tempatan termasuklah bantuan sara hidup, perubatan, perumahan, perniagaan/jaya diri, musibah, pembangunan dan pendidikan dan sebagainya. Bantuan-bantuan yang disalurkan juga melibatkan pelbagai lapisan masyarakat.

Di samping itu juga, kesemua institusi zakat telah pun memiliki laman sesawang masing-masing dengan memaparkan aktiviti, jumlah kutipan dan agihan, senarai bantuan yang disediakan, maklumat dan alamat pegawai yang bertugas dan sebagainya. Bagaimanapun, kebanyakan maklumat dalam laman sesawang tidak dikemaskini dengan baik dan tidak terkini. Terdapat juga maklumat yang disediakan bagi membantu pengguna untuk mendapatkan maklumat asas mengenai bantuan dan pegawai yang boleh dihubungi jika mereka memerlukan sebarang bantuan.

Jasa institusi zakat kepada masyarakat terutamanya orang Islam amatlah besar antaranya; skuad jejak asnaf diwujudkan, pelbagai program pembangunan ekonomi asnaf diadakan, bantuan bulanan kehidupan individu, keluarga dan saudara baru, skim biasiswa dan dermasiswa pelajar, dan lain-lain. Realitinya, saban tahun pihak institusi zakat telah memainkan peranan dan usaha yang penting dalam membantu membasmi kemiskinan di seluruh pelusuk tanah air. Institusi zakat juga telah berusaha menyampaikan maklumat kepada umum tentang usaha dan inisiatif bantuan yang telah diberikan melalui media perdana, media sosial dan sebaran secara hardcopy kepada seluruh daerah.

\section{Analisis Kandungan Keberkesanan Penggunaan Infografik}

Terdapat pelbagai kajian yang dilaksanakan dengan membangunkan infografik dalam penyelidikan. Dalam bahagian ini, sebanyak 29 artikel telah dikenalpasti menggunakan bahan infografik dalam penyelidikan yang mereka laksanakan. 
Jadual 2: Kajian Keberkesanan Penggunaan Infografik

\begin{tabular}{|c|c|c|c|}
\hline No. & Nama Penulis & Jenis Infografik & Dapatan Kajian \\
\hline 1. & Ho \& Mussap (2019) & $\begin{array}{l}\text { Scatter Plot 3D digunakan bagi } \\
\text { menggambarkan scala idenditi jantina. }\end{array}$ & $\begin{array}{l}\text { 'Scatter plot' merupakan pilihan yang tepat bagi mengklasifikasi jenis } \\
\text { jantina responden tanpa melakukan kesalahan dalam mengklasifikasikan } \\
\text { jantina responden. }\end{array}$ \\
\hline 2. & $\begin{array}{l}\text { Hubbard, Jones \& Gallardo- } \\
\text { Williams (2019) }\end{array}$ & $\begin{array}{l}\text { Jadual dan gambar rajah, bagi } \\
\text { memperkenalkan pengenalan } \\
\text { matapelajaran kimia organic kepada } \\
\text { pelajar. }\end{array}$ & $\begin{array}{l}\text { Terdapat maklum balas yang sangat positif terhadap jadual dan rajah } \\
\text { yang digunakan kerana meningkatkan kefahaman pelajar. }\end{array}$ \\
\hline 3. & Alyahya \& Nasser (2019) & $\begin{array}{l}\text { Penggunaan tiga warna utama; merah, } \\
\text { hijau \& cyan. }\end{array}$ & $\begin{array}{l}\text { Terdapat hubungan yang positif dalam penggunaan infografik bewarna } \\
\text { dengan kadar pemahaman dan ingatan pelajar. lanya turut membantu } \\
\text { pelajar untuk lebih memahami dan mengingati apa yang mereka lihat } \\
\text { dan baca. }\end{array}$ \\
\hline 4. & $\begin{array}{l}\text { Provvidenza, Hartman, } \\
\text { Carmichael \& Reed (2019) }\end{array}$ & Rajah pelbagai warna. & $\begin{array}{l}\text { Penggunaan infografik yang berbeza mengikut masa tertentu dapat } \\
\text { menyampaikan maklumat yang berkesan kepada pelbagai peringkat } \\
\text { umur. }\end{array}$ \\
\hline 5. & $\begin{array}{l}\text { Hohmann, Garza, Surry, Hansena } \\
\text { Ilene Harris, Kiptanui, Oguntimein, } \\
\text { Frost \& Qian (2019) }\end{array}$ & Rajah dan jadual & $\begin{array}{l}\text { Selain menjimatkan kos, penggunaan infografik dapat menyampaikan } \\
\text { maklumat dengan padat dan berkesan tanpa perlu menakutkan } \\
\text { pembaca. }\end{array}$ \\
\hline 6. & $\begin{array}{l}\text { Huang, Martin, Yeh, Chin, } \\
\text { Murray, Sanderson, Mohindra, } \\
\text { Chan \& Thoma (2018) }\end{array}$ & Rajah dan jadual & $\begin{array}{l}\text { Kesedaran berkenaan ilmu perubatan dapat disampaikan kepada } \\
\text { pelbagai lapisan masyarakat. }\end{array}$ \\
\hline 7. & Pinto, Pascual \& Sales (2018) & Rajah dan jadual & $\begin{array}{l}\text { Penggunaan bahan infografik seperti rajah dan jadual dapat } \\
\text { meningkatkan tahap kesedaran pemegang saham dalam kepentingan } \\
\text { untuk menggalakkan kebolehan profesionalisma di masa akan datang. }\end{array}$ \\
\hline 8. & Royal \& Erdmann (2018) & Rajah dan jadual & $\begin{array}{l}\text { Penggunaan infografik sebagai medium perantara untuk menyampaikan } \\
\text { maklumat telah menjadi semakin popular dan disenangi ramai. }\end{array}$ \\
\hline 9. & Fadzil (2018) & Rajah dan jadual & $\begin{array}{l}\text { Infografik membantu pelajar tadika memahami sesuatu dengan lebih } \\
\text { mudah di samping meningkatkan kemahiran tenaga pengajar tadika } \\
\text { dalam menguasai bidang teknologi. }\end{array}$ \\
\hline
\end{tabular}




\begin{tabular}{|c|c|c|c|}
\hline 10. & Damyanov \& Tsankov (2018) & Rajah dan jadual & $\begin{array}{l}\text { Terdapat peluang yang baik dalam menggunakan infografik bagi } \\
\text { membangunkan sistem yang komprehensif. }\end{array}$ \\
\hline 11. & Afify (2018) & Rajah dan jadual & $\begin{array}{l}\text { Infografik lebih memberi kesan positif dalam mengasah bakat dan } \\
\text { membantu meningkatkan ingatan berbanding pembelajaran jenis audio. }\end{array}$ \\
\hline 12. & $\begin{array}{l}\text { Baglama, Yücesoy, Uzunboylu \& } \\
\text { Ozcan (2017) }\end{array}$ & Rajah dan jadual & $\begin{array}{l}\text { Infografik meningkatkan minat, motivasi dan pencapaian murid dalam } \\
\text { pembelajaran matematik. }\end{array}$ \\
\hline 13. & $\begin{array}{l}\text { Wongpa, Tanamai \& Diteeyont } \\
\text { (2017) }\end{array}$ & Rajah dan jadual & $\begin{array}{l}\text { Infografik membantu pelajar untuk memahami dengan lebih cepat dan } \\
\text { mudah, dapat menyampaikan maklumat dengan cepat dan jelas tanpa } \\
\text { memerlukan huraian yang panjang. }\end{array}$ \\
\hline 14. & $\begin{array}{l}\text { Mahmoudi \& Mojtahedi Shams } \\
\text { (2017) }\end{array}$ & Rajah dan jadual & $\begin{array}{l}\text { Infografik meningkatkan kebolehan belajar tanpa mengira jenis ilmu } \\
\text { yang disampaikan. }\end{array}$ \\
\hline 15. & Ryerson (2017) & Rajah dan jadual & $\begin{array}{l}\text { Infografik digunakan sebagai bahan pembelajaran yang efektif di sekolah } \\
\text { disebabkan penggunaan rajah bewarna yang mudah difahami. }\end{array}$ \\
\hline 16. & $\begin{array}{l}\text { Locoro, Cabitza, Grosso \& Batini } \\
\text { (2017) }\end{array}$ & Rajah dan jadual & $\begin{array}{l}\text { Pelajar universiti lebih suka penggunaan infografik yang menarik } \\
\text { khususnya berkenaan kedudukan universiti dan ramalan cuaca. }\end{array}$ \\
\hline 17. & $\begin{array}{l}\text { Gallagher, O’Dulain, O’Mahony \& } \\
\text { Kehoe (2017) }\end{array}$ & Rajah dan jadual & $\begin{array}{l}\text { Infografik sangat berguna dalam menjelaskan sesuatu bagi memahami } \\
\text { konsep pembelajaran. }\end{array}$ \\
\hline 18. & $\begin{array}{l}\text { Taspolat, Kaya, Sapanca, Beheshti } \\
\text { \& Ozdamli (2017) }\end{array}$ & Rajah dan jadual & $\begin{array}{l}\text { Infografik membantu tenaga pengajar bagi menyampaikan maklumat } \\
\text { yang kompleks menjadi lebih mudah. }\end{array}$ \\
\hline 19. & Zhang (2016) & Rajah dan jadual & $\begin{array}{l}\text { Infografik boleh menyampaikan maklumat kualitatif dengan tepat dan } \\
\text { lengkap. }\end{array}$ \\
\hline 20. & Bradhaw (2017) & Rajah dan jadual & $\begin{array}{l}\text { Infografik digunakan oleh jururawat bagi menyampaikan maklumat } \\
\text { kepada pesakit. }\end{array}$ \\
\hline 21. & Wansink, Robbins (2016) & Rajah dan jadual & Infografik lebih menarik dan mudah diingati. \\
\hline 22. & Ahmed, Lee \& Struik (2016) & Rajah dan jadual & $\begin{array}{l}\text { Infografik mampu mecapai pembaca yang ramai kerana mempunyai } \\
\text { kelebihan menyampaikan maklumat yang padat dalam pelbagai bentuk. }\end{array}$ \\
\hline 23. & Yildirim (2016) & Rajah dan jadual & $\begin{array}{l}\text { Infografik dianggap sebagai salah satu bahan pengajaran asas kerana } \\
\text { kebolehan infografik membantu meingkatkan ingatan pembaca dengan } \\
\text { lebih baik. }\end{array}$ \\
\hline 24. & Lee \& Cavanaugh (2016) & Rajah dan jadual & $\begin{array}{l}\text { Infografik boleh menjadi kaedah yang berkesan untuk memperkenalkan } \\
\text { inovasi teknologi dalam pengurusan sukan. }\end{array}$ \\
\hline
\end{tabular}




\begin{tabular}{|c|c|c|c|}
\hline 25. & $\begin{array}{l}\text { Bellsky, Usenyuk \& Polyakova } \\
\text { (2015) }\end{array}$ & Rajah dan jadual & $\begin{array}{l}\text { Infografik boleh digunakan sebagai bahan pengajaran yang baik di dalam } \\
\text { kelas. }\end{array}$ \\
\hline 26. & Lee \& Cavanaugh (2016) & Rajah dan jadual & $\begin{array}{l}\text { Penggunaan infografik dalam resume dibuktikan lebih manarik perhatian } \\
\text { majikan. }\end{array}$ \\
\hline 27. & $\begin{array}{l}\text { Arcial, Suero-Tajeda, Bales, } \\
\text { Merrill, Yoon \& Bakken (2015) }\end{array}$ & Rajah dan jadual & $\begin{array}{l}\text { Disebabkan infografik sangat padat dengan maklumat, ia menjadi } \\
\text { medium yang sangat baik dalam menyampaikan maklumat yang padat. }\end{array}$ \\
\hline 28. & Poliakoff \& Tang (2015) & Rajah dan jadual & Infografik mudah difahami oleh kebanyakkan orang. \\
\hline 29. & $\begin{array}{l}\text { Niebaum, Sabo, Carroll \& Bellows } \\
(2015)\end{array}$ & Rajah dan jadual & $\begin{array}{l}\text { Pendidik dapat menarik perhatian pengguna dan menyampaikan mesej } \\
\text { pendidikan yang bermakna menggunakan infografik. }\end{array}$ \\
\hline
\end{tabular}


Jadual 2 di atas menunjukkan 29 artikel yang telah dikenalpasti dalam pangkalan data Scopus. Sebanyak 29 kajian membuktikan bahawa penggunaan infografik berkesan dalam menyampaikan maklumat kepada pengguna. Hasil analisis dari artikel di atas menunjukkan bahawa infografik telah digunakan secara meluas dalam pelbagai bidang merangkumi pendidikan, sukan, sains, kesihatan, teknologi, ekonomi dan perniagaan. Berdasarkan kepada Rajah 1, terdapat empat tema yang terbentuk hasil dari perbincangan yang dipaparkan, iaitu; (1) Infografik memudahkan maklumat yang banyak dan kompleks; (2) infografik membantu pengguna mengingati fakta; (3) Infografik sesuai digunakan untuk semua lapisan masyarakat, dan; (4) Kombinasi warna infografik berperanan penting. Huraian terperinci setiap tema dijelaskan dalam bahagian seterusnya.

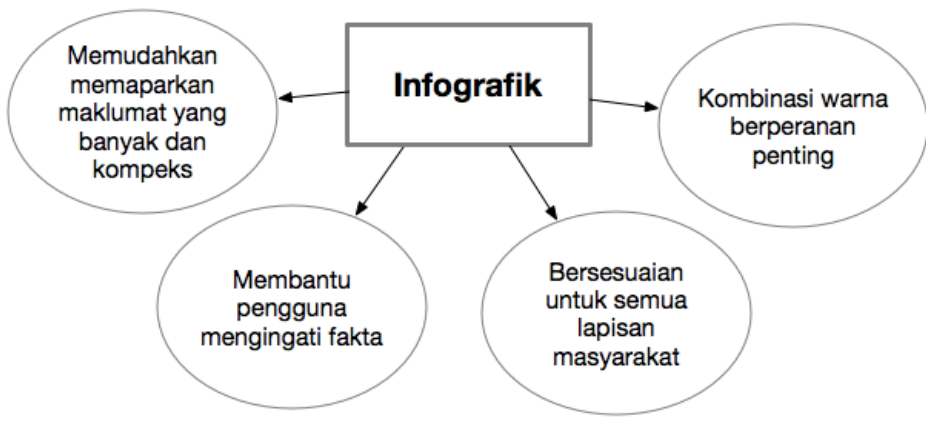

Rajah 6: Tema Dapatan Analisis Kandungan

\section{Infografik Memudahkan Maklumat yang Banyak dan Kompleks}

Berdasarkan dapatan di atas, Baglama (2017) mendapati bahawa bahan pembelajaran berbentuk infografik diminati oleh kebanyakan pelajar. Bahkan, kajian oleh Afify (2018) turut menegaskan bahawa penggunaan infografik lebih memberi kesan berbanding penggunaan audio dalam pembelajaran. Keadaan ini dibuktikan dengan kajian yang dilaksanakan oleh Taspolat et al. (2017), Fadzil (2018), Wongpa, Tanamai dan Diteeyont (2017). Bukan sekadar itu sahaja, penggunaan infografik mampu menyampaikan maklumat yang banyak dan kompleks menjadi lebih mudah untuk mendapatkan maklumat dengan segera (Taspolat Kaya, Sapanca, Beheshti \& Ozdamli, 2007; Huang, Martin, Yeh, Chin, Murray, Sanderson, Mohindra, Chan \& Thoma, 2018; Bradhaw, 2017). Bradhaw (2017) pula mendapati bahawa pesakit di hospital berpotensi untuk mengetahui maklumat kesihatan menerusi infografik dengan lebih mudah. Manakala Lee dan Cavanaugh (2016) pula mendedahkan bahawa penggunaan infografik dalam resume memudahkan majikan untuk memilih dan mencari pekerja. Kesemua dapatan ini menunjukkan bahawa infografik dapat digunakan untuk memudahkan pelbagai maklumat yang banyak dan kompleks dengan cara yang efisyen.

\section{Infografik Membantu Pengguna Mengingati Fakta}

Selain itu, penggunaan infografik memberi impak yang baik kepada memori pengguna. Kajian oleh Alyahya dan Nasser (2019), Afify (2018), Wansink dan Robbins (2016) serta Yildirim (2016), menyatakan bahawa infografik membantu pengguna untuk mengingati fakta dengan cepat. Di samping itu jugam mereka bersetuju untuk menyatakan bahawa penggunaan infografik memberi kesan memori ingatan bertahan lebih lama kepada minda pengguna.

Kajian lain turut mendapat dapatan yang hampir sama iaitu wujud hubungan yang positif dalam penggunaan infografik terhadap kadar pemahaman dan ingatan pengguna (Alyahya \& Nasser, 2019; Hubbard, Jones \& Gallardo-Williams, 2019; Gallagher, O’Dulain, 
O'Mahony \& Kehoe, 2017). Dapatan ini menggambarkan bahawa penggunaan infografik dapat membantu pengguna mengingati fakta dengan mudah dan ianya bertahan lebih lama dalam minda pengguna berbanding dengan cara yang biasa digunakan seperti membaca teks.

\section{Infografik Sesuai Untuk Semua Lapisan Masyarakat}

Menurut kajian yang dilakukan oleh Provvidenza, Hartman, Carmichael dan Reed (2019) serta Huang, Martin, Yeh, Chin, Murray, Sanderson, Mohindra, Chan dan Thoma (2018), penggunaan infografik bersesuaian dengan pelbagai umur pengguna. Bahkan dapatan kajian mereka turut mengakui bahawa penggunaan infografik mudah difahami oleh pengguna dari pelbagai jenis lapisan umur, bermula daripada bangku sekolah hingga kepada golongan tua. Malahan, penggunaan infografik yang sesuai untuk semua lapisan masyarakat dapat mengurangkan kadar perbelanjaan dalam pengiklanan dan penyampaian maklumat (Hohmann, Garza, Surry, Hansena llene Harris, Kiptanui, Oguntimein, Frost \& Qian, 2019). Keadaan ini sememangnya dapat menjimatkan kos pihak tertentu dalam menyampaikan maklumat. Hal ini kerana, pihak tertentu tidak perlu menggunakan medium yang berbeza untuk menyampaikan maklumat yang sama kepada golongan yang berbeza. Oleh yang demikian, penggunaan infografik berdasarkan dari beberapa artikel dalam tema ini mengambarkan bahawa ianya sesuai untuk semua lapisan masyarakat di samping dapat menjimatkan kos percetakan.

\section{Kombinasi Warna dalam Infografik Berperanan Penting}

Pemilihan warna dalam infografik turut memainkan peranan yang penting. Kajian Alyahya dan Nasser, (2019) dan juga Ryerson (2017) mendapati bahawa penggunaan warna yang berbeza memudahkan pengguna membezakan sesuatu fakta. Bahkan kajian mereka turut mengakui bahawa penggunaan infografik yang melibatkan sebarang data bewarna dapat memudahkan pengguna untuk memahami dengan baik. Alyahya dan Nasser (2019) serta Ryerson (2017) turut menyatakan bahawa pemilihan warna tertentu atau penggunaan warna yang terpilih dalam infografik dapat mempengaruhi pengguna dengan baik. Ini termasuklah penggunaan data perbandingan, perbezaan nombor dan sebagainya. Penggunaan warna ini dapat memberi kesan kepada pengguna dengan lebih baik. Ini menunjukkan bahawa penggunaan kombinasi warna yang tertentu dalam infografik memainkan peranan yang penting dalam persembahan.

\section{PERBINCANGAN}

Berdasarkan dari analisis dapatan di dalam jadual 1, majoriti institusi zakat di Malaysia mempunyai pengikut dari pelbagai laman sosial media dengan jumlah pengikut yang tinggi. Pengikut di Facebook dari jumlah 5,134 orang pengguna (MAIK) hingga ke 251,170 orang pengguna (LZS); Pengikut Twitter dari 36 orang pengguna (@baitulmakswk) hingga ke 2,316 orang pengguna (@ppzwp); pengikut Instagram dari 14 orang pengguna hingga ke 15,900 orang pengguna (@zakatselangor). Walaupun terdapat institusi zakat yang masih belum menggunakan secara menyeluruh media sosial ini namun, data yang dipamerkan ini meningkat dari semasa ke semasa. Kadar jumlah pengguna yang tinggi ini menunjukkan bahawa pengguna sedar dan mengetahui sebarang aktiviti yang dijalankan oleh mana-mana institusi sepanjang masa. Ini merupakan peluang yang besar bagi institusi zakat untuk memaparkan dan menyebarluaskan sebarang kegiatan atau aktiviti yang dilaksanakan dari semasa ke semasa kepada netizen. Tindakan pembaca seperti like, sharing atau comment dalam media sosial memberi maksud yang tersirat. Menurut Nisar dan Whitehead (2016), 
tahap kepercayaan dan keyakinan pengguna dalam media sosial dapat ditonjolkan melalui aktiviti dalam talian seperti like, share dan comments pada setiap post yang dipaparkan. Pada masa yang sama, institusi zakat dapat mengetahui dan menangani tanggapan negatif netizen dalam talian.

Selain itu, pengguna kebiasaannya akan cenderung untuk like status yang bergambar dan memberi komen pada status yang meminta maklum balas atau bermaklumat. Manakala status bergambar atau video yang mempunyai unsur nilai-nilai murni pula akan dikongsi oleh pembaca. Sebaliknya, post yang mempunyai nilai negatif atau membangga diri akan diabaikan oleh pembaca. Hal ini diakui oleh Kim dan Yang (2017) dan Rush dan Cameron (2016) di mana kajian mereka mendedahkan bahawa perkongsian status dari media sosial menjadikan pengguna lebih prihatin terhadap sebarang aktiviti yang dijalankan. Tindakan like, share dan komen juga memberi tanda bahawa tingkah laku pengguna dalam dunia digital merupakan cerminan untuk mengetahui sama ada sesuatu mesej yang disampaikan itu berkesan atau tidak.

Dari perspektif psikologi, aktiviti dalam media sosial (like, post, sharing dan comment) merupakan gambaran atau luahan emosi secara virtual (Carrier et al., 2015). Kajian Nawi, Hussin, Ren, Norsaidi dan Pozi (2020) mendedahkan bahawa segala aktiviti pengguna secara dalam talian merupakan cerminan personaliti seseorang. lanya turut memberi impak kepada pembaca terutamanya apabila 'status' berkenaan mempunyai perkaitan langsung dengan pembaca dalam kehidupan sebenar. Salah satu contoh 'status' yang memberi impak terhadap pembaca apabila ianya menjadi viral dalam sesebuah komuniti. Melalui pemerhatian Berger (2014), terdapat enam ciri status yang berpotensi menjadikan sesuatu 'status' tersebut viral, iaitu; 1) perkongsian bermaklumat; 2) mempunyai unsur tarikan kekal; 3) menyentuh emosi; 4) membawa nilai peribadi bersama; 5) nilai yang praktikal; 6) berkaitan isu semasa. Status yang viral juga berpotensi untuk memberi tarikan, kesedaran dan perubahan terhadap tingkah laku dalam sesebuah kumpulan dalam media sosial (Alhabash et al., 2018).

Selain itu juga, penggunaan infografik memberikan kesan positif dalam pelbagai aspek. Sebagai contoh, penggunaan infografik dapat membantu dari segi pemahaman, menarik minat pembaca dan meningkatkan penyampaian maklumat dengan segera. Kajian lepas turut membuktikan bahawa penggunaan infografik berjaya menyampaikan maklumat dengan berkesan dalam membantu pembaca memahami pelbagai jenis maklumat (Hubbard, Jones \& Gallardo-Williams, 2019; Sharudin, Mustaffa \& Sannusi, 2020; Taspolat et al., 2017; Bellsky, Usenyuk, \& Polyakova, 2015). Sehubungan dengan itu, beberapa pengkaji seperti Alyahya dan Nasser (2019), Hubbard, Jones dan Gallardo-Williams (2019), serta Wongpa, Tanamai dan Diteeyont (2017) turut menegaskan bahawa penggunaan infografik bukan sahaja membantu dari segi pemahaman pelajar, malah telah dibuktikan bahawa informasi yang diterima oleh pelajar akan kekal lebih lama dalam ingatan mereka. Penyampaian maklumat berbentuk infografik turut berjaya melangkaui pelbagai jenis lapisan masyarakat tanpa mengira batasan umur pengguna (Provvidenza, Hartman, Carmichael \& Reed, 2019). Ini menunjukkan bahawa penggunaan infografik merupakan salah satu medium penyampaian yang efektif dan menarik yang boleh digunakan oleh mana-mana institusi secara dalam talian.

Kajian-kajian lepas turut membuktikan bahawa penggunaan infografik amat berguna untuk menyebarluas maklumat seperti; kegunaan untuk membina kesedaran (Kadri et al., 2016) dan menarik perhatian supaya meningkat kepercayaan dalam kalangan pengguna (Parrish, 2016). Infografik turut digunakan dengan berkesan oleh pelbagai syarikat dalam pemasaran untuk meningkatkan kepercayaan terhadap jenama mereka (Lee \& Cavanaugh, 
2016). Selain itu, infografik turut digunakan dalam perundingan untuk menggambarkan tempoh masa projek (Hidayah, 2018), membuat gambaran terhadap dapatan penyelidikan (Nawi \& Zakaria, 2016; Nawi, Hamzah \& Abdul-Rahim, 2015) dan menjimatkan kos (Taspolat et al., 2017). Penggunaan pendekatan menakut-nakutkan masyarakat tentang bahaya dan risiko penyakit telah lama digunakan terumanya dalam bidang kesihatan. Namun, pendekatan ini semakin kurang digunakan sejak wujudnya infografik untuk memberikan kesedaran kepada masyarakat bekenaan kepentingan menjaga kesihatan tanpa perlu menggunakan pendekatan mengancam atau menakutkan masyarakat. Oleh yang demikian, penggunaan infografik membuka ruang dan peluang yang besar dalam menyampaikan maklumat dengan segera, menjimatkan kos dan meningkatkan kefahaman, kepercayaan dan keyakinan pengguna dalam talian.

\section{KESIMPULAN \& CADANGAN}

Selaras dengan perkembangan semasa, pembangunan bahan multimedia seperti infografik amat diperlukan bagi menyebarluaskan maklumat. Institusi zakat telah pun mempunyai peluang untuk meningkatkan kepercayaan dan keyakinan netizen dengan memaksimumkan kepelbagaian penyampaian yang ada di dalam media sosial. Antara penyampaian yang berkesan ialah dengan menggunakan pendekatan infografik. Penggunaan infografik ini dapat membantu institusi zakat meningkatkan kepercayaan dan keyakinan netizen secara dalam talian. Bukan itu sahaja, institusi zakat juga dapat menggunakan infografik sebagai salah satu cara untuk menjawab sebarang persoalan atau kemusykilan yang diajukan oleh netizen. Bahkan, penyediaan sumber bahan bermaklumat secara dalam talian amatlah diperlukan seiring dengan perkembangan dunia digital pada hari ini (Nawi, Zakaria, Hashim Mahalle \& Ren, 2020). Maklum balas yang berkala dan segera juga amat penting dalam menangani sebarang tanggapan negatif netizen di dalam talian.

Institusi zakat juga dicadangkan agar dapat mengenalpasti bahan dan reka bentuk infografik yang bersesuaian agar kandungan yang dipaparkan dapat difahami dengan baik dan cepat. Bahan yang direkabentuk juga haruslah mempunyai kualiti yang baik dan bermutu agar dapat memastikan mesej yang disampaikan bergerak lebih jauh dalam media sosial. Pemilihan bahasa juga berperanan untuk menarik minat dan memberi pengaruh yang tinggi kepada pengguna terutamanya dalam media sosial (Ma'alip, 2015; Nawi \& Zakaria, 2019). Tambahan juga, infografik juga boleh digunakan untuk berkongsi statistik agihan dan kutipan zakat terkini, agihan yang disalurkan, jumlah penerima atau asnaf telah memperoleh manfaat dan sebagainya.

Di samping itu, mesej yang terkandung dalam infografik juga perlu seiring dengan isu terkini dan dimasukkan berkaitan usaha dan inisiatif yang telah dijalankan institusi zakat. Bagi merealisasikan usaha ini, institusi zakat dicadangkan agar mewujudkan bahagian khas untuk menyelia sebarang usaha dan pembangunan infografik menerusi sebaran maklumat di media sosial. Mewujudkan peluang untuk mengambil pelajar dalam latihan industri yang mempunyai kepakaran dalam membangunkan pelbagai bahan media turut dapat membantu bahagian khas ini. Kewujudan bahagian khusus media sosial dalam sesebuah institusi zakat perlu dipertimbangkan bagi melancarkan lagi perlaksanaan pembangunan bahan infografik atau bahan multimedia lain secara dalam talian.

Selain itu, kepelbagaian reka bentuk dan pemilihan warna dalam infografik juga perlu diambilkira supaya ianya kekal relevan pada bila-bila masa. Sebagai contoh penggunaan infografik yang statik dibuat dalam bentuk visual statik, tanpa konsep audio atau konsep animasi yang boleh bergerak. Manakala penggunaan infografik animasi digunakan pada 
media audio visual seperti televisyen atau youtube. la disediakan dalam bentuk 2 atau 3 dimensi; atau penggunaan infografik lebih kompleks iaitu infografik interaktif kerana memerlukan kerjasama dengan pembangun (developer) atau programmer supaya animasi atau program interaksi boleh dijalankan dengan lancar.

Oleh yang demikian, pengintegrasian maklumat menerusi infografik yang berkesan bukan sahaja bakal memperkasakan institusi zakat sebagai pemegang amanah, malahan juga boleh membantu mempromosikan institusi zakat sebagai institusi yang diyakini oleh masyarakat untuk membasmi kemiskinan. Ekoran itu, imej institusi zakat bakal diberi pengiktirafan oleh netizen dan meningkatkan kepercayaan masyarakat dengan bertambahnya pembayar zakat di seluruh Malaysia. Cadangan untuk membangunkan maklumat usaha dan inisiatif menerusi penggunaan infografik di media sosial atau laman sesawang oleh institusi zakat di Malaysia adalah bertepatan dengan dunia semasa yang memerlukan informasi yang pantas dan segera.

\section{PENGHARGAAN}

Kajian ini dibiayai oleh Geran Penyelidikan dari Lembaga Zakat Negeri Kedah (LZNK) dan Institut Penyelidikan \& Inovasi Zakat Universiti Utara Malaysia (IPIZ UUM) dengan rujukan Kod SO 14292.

\section{BIODATA}

Aliff Nawi, PhD Pensyarah Kanan di Pusat Pengajian Pendidikan \& Bahasa Moden, UUM. Bidang kajian beliau berkaitan dengan Agama, Pendidikan, Moral \& Etika dalam persekitaran digital dengan menggunakan pelbagai perisian statistik, Al dan Data Raya. E-mel: aliffnawi@yahoo.com

Mohd Zailani Mohd Yusoff, Profesor Madya di di Pusat Pengajian Pendidikan \& Bahasa Moden, UUM. Bidang kajian beliau berkaitan Pendidikan Moral dan Etika, Pendidikan Nilai, Psikologi Moral dan Perbandingan Agama. E-mel: myzailani@uum.edu.my

Chua Chy Ren, a lecturer in School of Business and Social Sciences in Albukhary International University. Her research interests include Digital Economy, International Trade and Financial Economics. E-mel: safiyya.chua@aiu.edu.my

Ahmad Sahidah, PhD pensyarah di Universitas Nurul Jadid Paiton Probolinggo Jawa Timur, Indonesia. Bidang kajian beliau berkaitan dengan Falsafah dan Pemikiran, Perbandingan Agama dan Pendidikan Islam. E-mel: ahmadsahidah@gmail.com 


\section{RUJUKAN}

Afify, M. K. (2018). The effect of the difference between infographic designing types (static vs animated) on developing visual learning designing skills and recognition of its elements and principles. International Journal of Emerging Technologies in Learning, 13(9), 204-223. https://doi.org/10.3991/ijet.v13i09.8541

Ahmed, O. H., Lee, H., \& Struik, L. L. (2016). A picture tells a thousand words: A content analysis of concussion-related images online. Physical Therapy in Sport, 21, 82-86. https://doi.org/10.1016/i.ptsp.2016.03.001

Alhabash, S., Almutairi, N., Lou, C., \& Kim, W. (2018). Pathways to virality: Psychophysiological Responses preceding likes, shares, comments, and status updates on Facebook. Media Psychology, 1-21. https://www.doi.org/10.1080/15213269.2017.1416296

Alyahya, D., \& Nasser, R. (2019). Message design: Color impact and its effectiveness on designing instructional infographic. International Journal of Learning, Teaching and Educational Research, 18(2), 43-64. https://doi.org/10.26803/ijlter.18.2.4

Arcia, A., Suero-Tejeda, N., Bales, M. E., Merrill, J. A., Yoon, S., Woollen, J., \& Bakken, S. (2016). Sometimes more is more: Iterative participatory design of infographics for engagement of community members with varying levels of health literacy. Journal of the American Medical Informatics Association, 23(1), 174-183. https://doi.org/10.1093/jamia/ocv079

Aujoulat, N. (2005). The splendour of Lascaux: Rediscovering the greatest treasure of prehistoric art. Thames \& Hudson.

Baglama, B., Yucesoy, Y., Uzunboylu, H., \& Özcan, D. (2017). Can infographics facilitate the learning of individuals with mathematical learning difficulties? International Journal of Cognitive Research in Science, Engineering and Education, 5(2), 119-128. https://doi.org/10.5937/IJCRSEE1702119B

Berger, J., (2014). Contagious: How to build word of mouth in the digital age (2nd ed.). Simon \& Schuster UK Ltd.

Bradshaw, M. J., \& Porter, S. (2017). Infographics: A new tool for the nursing classroom. Nurse Educator, 42(2), 57-59. https://doi.org/10.1097/NNE.0000000000000316

Bradford, W. C. (2004). Reaching the visual learner: Teaching property through art. The Law Teacher, 11. https://ssrn.com/abstract $=587201$

Budge, E. A. W. (1920). An Egyptian hieroglyphic dictionary. John Murray.

Carrier, L. M., Spradlin, A., Bunce, J. P., \& Rosen, L. D. (2015). Virtual empathy: Positive and negative impacts of going online upon empathy in young adults. Computers in Human Behavior, 52, 39-48.

Costigan-Eaves, P., \& Macdonald-Ross, M. (1990). William Playfair (1759-1823). Statistical Science, 5(3), 318-326. www.jstor.org/stable/2245819

Damyanov, I., \& Tsankov, N. (2018). The role of infographics for the development of skills for cognitive modeling in education. International Journal of Emerging Technologies in Learning, 13(1), 82-92. https://doi.org/10.3991/ijet.v13i01.7541

Elena Gallagher, S., O’Dulain, M., O'Mahony, N., Kehoe, C., McCarthy, F., \& Morgan, G. (2017). Instructor-provided summary infographics to support online learning. Educational Media International, 54(2), 129-147. https://doi.org/10.1080/09523987.2017.1362795

Fadzil, H. M. (2018). Designing infographics for the educational technology course: Perspectives of preservice science teachers. Journal of Baltic Science Education, 17(1), 8-18. 
Field, K., \& Cartwright AM, W. (2014). Becksploitation: The over-use of a cartographic icon. The Cartographic Journal, 51(4), 343-359. https://doi.org/f6sk96

Gittins, R., \& Pettitt, P. (2017). Is Palaeolithic cave art consistent with costly signalling theory? Lascaux as a test case. World Archaeology, 49(4). https://doi.org/f3dp

Hafizah Zainal. (2017). Penentu kepercayaan terhadap institusi zakat: Kajian dalam kalangan pihak berkepentingan di negeri Kedah [Tesis Doktor Falsafah, Universiti Utara Malaysia].

Hairunnizam Wahid, Sanep Ahmad, \& Radiah Abdul Kader. (2009). Pengagihan zakat oleh institusi zakat di Malaysia: Mengapa masyarakat Islam tidak berpuas hati?. Jurnal Syariah, 17(1), 89-112.

Hashim, N., \& Razali, A. (2019). Teknologi dan media sosial dalam komunikasi ibubapa dan anak-anak. Jurnal Komunikasi: Malaysian Journal of Communication, 35(4), 337-352.

Hidayah Mohd Fadzil. (2018). Designing infographics for the educational technology course: Perspectives of preservice science teachers. Journal of Baltic Science Education, 17(1), 8-18.

Ho, F., \& Mussap, A. J. (2019). The gender identity scale: Adapting the gender unicorn to measure gender identity. Psychology of Sexual Orientation and Gender Diversity, 6(2), 217-231. https://doi.org/10.1037/sgd0000322

Hohmann, N. S., Garza, K. B., Surry, D., Hansen, R. A., Harris, I., Kiptanui, Z., Oguntimein, O., Frost, M. M., \& Qian, J. (2019, Jan). Communicating benefits and risks of generic drugs to consumers: Patient and caregiver opinions of two FDA-developed educational materials. Research in Social and Administrative Pharmacy, 0-1. https://www.doi.org/10.1016/i.sapharm.2019.01.013

Holmes, N. (2000). Pictograms: A view from the drawing board or, what I have learned from Otto Neurath and Gerd Arntz (and jazz). Information Design Journal, 10(2), 133-143.

Huang, S., Martin, L. J., Yeh, C. H., Chin, A., Murray, H., Sanderson, W. B., Mohindra, R., Chan, T. M., \& Thoma, B. (2018). The effect of an infographic promotion on research dissemination and readership: A randomized controlled trial. Canadian Journal of Emergency Medicine, 20(6), 826-833. https://www.doi.org/10.1017/cem.2018.436

Hubbard, B. A., Jones, G. C., \& Gallardo-Williams, M. T. (2019). Student-generated digital tutorials in an introductory organic chemistry course. Journal of Chemical Education, 96(3), 597-600. https://www.doi.org/10.1021/acs.jchemed.8b00457

Kadri, S. M., Saleem-ur-Rehman, Kausar, R., \& Gergianaki, I. (2016). Zika Virus Disease (ZIKV) Infographics, language-tailored: Innovations and good practices in integrated disease surveillance programme Kashmir, India. Journal of MPE Molecular Pathological Epidemiology, 1(7), 1-4.

Kim, C., \& Yang, S. U. (2017). Like, comment, and share on Facebook: How each behavior differs from the other. Public Relations Review, 43(2), 441-449. https://www.doi.org/10.1016/i.pubrev.2017.02.006

Krystian, M. (2016). Data visualization: A brief look at the fascinating history of infographics. Infogram (Blog section). https://infogram.com/blog/a-brief-look-at-the-fascinating

Lee, J. W., \& Cavanaugh, T. (2016). Building your brand: The integration of infographic resume as student self-analysis tools and self-branding resources. Journal of Hospitality, Leisure, Sport \& Tourism Education, 18, 61-68. https://doi.org/gdz5sc

Lembaga Zakat Negeri Kedah (Portal rasmi). (t.th.). Perumahan: Bantuan kepada individu. https://www.zakatkedah.com.my/senarai-bantuan/\#1479711978265-1eaf2c29-9f37 
Locoro, A., Cabitza, F., Actis-Grosso, R., \& Batini, C. (2017). Static and interactive infographics in daily tasks: A value-in-use and quality of interaction user study. Computers in Human Behavior, 71, 240-257. https://doi.org/10.1016/i.chb.2017.01.032

Ma'alip, S. (2015). Pemilihan bahasa dalam komunikasi di laman sosial (Language choice of communication on social networking site). Jurnal Komunikasi: Malaysian Journal of Communication, 31(2), 231-246. https://doi.org/f3dr

Mackey, A., \& Bassendowski, S. (2017). The history of evidence-based practice in nursing education and practice. Journal of Professional Nursing, 33(1), 51-55. https://doi.org/10.1016/j.profnurs.2016.05.009

Mahmoudi, M. T., Mojtahedi, S., \& Shams, S. (2017). AR-based value-added visualization of infographic for enhancing learning performance. Computer Applications in Engineering Education, 25(6), 1038-1052. https://doi.org/10.1002/cae.21853

Maryam Abd Rashid, Hairunnizam Wahid, \& Sanep Ahmad. (2018). Analisis faktor penentu kualiti pengurusan zakat: Kajian terhadap Lembaga Zakat Selangor (LZS) di Sepang. Journal of Fatwa Management and Research, 11(1), 27-44.

Meinert, J., Mirbabaie, M., Dungs, S., \& Aker, A. (2018). In Meiselwitz G. (Ed.), Social computing and social media: User experience and behavior [SCSM 2018, Lecture notes in computer science, Vol. 10913]. Springer. https://doi.org/f3ds

Meyers, P. D., \& McNicholas, M. J. (2008). Improved data illustration in complex multiligament knee reconstruction surgery: Using the historical principles of Florence Nightingale and John Venn. Acta Orthopaedica, 79(2), 244-248. https://doi.org/10.1080/17453670710015049

Nawi, A., Hussin, Z., Ren, C. C., Norsaidi, N. S., \& Pozi, M. S. M. (2020). Identifying the types of digital footprint data used to predict psychographic and human behaviour. Proceedings of the 22nd International Conference on Asia-Pacific Digital Libraries (ICADL 2020), LNCS 12504 (pp. 1-7).

Nawi, A., \& Zakaria, G. A. N. (2016). Pembangunan \& penilaian portal IPBL dalam kursus Pendidikan Islam di Politeknik Brunei. Jurnal Komunikasi: Malaysian Journal of Communication, 32(1), 261-285.

Nawi, A., Zakaria, G. A. N., Hashim, N., Mahalle, S., \& Ren, C. C. (2020). The needs of Islamic digital resources in Polytechnic Brunei Darussalam: A preliminary study. International Journal of Instruction, 13(1), 225-234. http://repo.uum.edu.my/27274/

Nawi, A., \& Zakaria, G. A. N. (2019). The impact of applying religious values through online problem-based learning among undergraduate students: A quasi-experimental study. International Journal of Learning, Teaching and Educational Research, 18(8), 192-213.

Nawi, A. , Hamzah, M. I., \& Abdul Rahim, A. A. (2015). Teachers acceptance of mobile learning for teaching and learning in Islamic education: A preliminary study. Turkish Online Journal of Distance Education, 16(1), 184-192.

Niebaum, K., Cunningham-Sabo, L., Carroll, J., \& Bellows, L. (2015). Infographics: “An innovative tool to capture consumers" attention. Journal of Extension, 53(6).

Nightingale, F. (1858). Notes on matters affecting the health, efficiency and hospital administration of the British army. Royal Collection Trust.

Ozdamli, F., \& Ozdal, H. (2018). Developing an instructional design for the design of infographics and the evaluation of infographic usage in teaching based on teacher and student opinions. EURASIA Journal of Mathematics, Science and Technology Education, 14(4), 1197-1219. 
Parrish, C. P. (2016). Exploring visual prevention: Developing infographics as effective cervical cancer prevention for African American women [PhD thesis, Virginia Commonwealth University, Richmond, Virginia].

Pinto, M., Fernandez-Pascual, R., \& Sales, D. (2018). Communication of information in the digital age among social sciences students: Uncovering a synthetic indicator of performance. Aslib Journal of Information Management, 70(4), 326-343. https://www.doi.org/10.1108/AJIM-02-2018-0035

Piotti, S., \& Murphy, A. C. (2019). A cognitive, socio-semiotic, linguistic, and discursive approach to popularisation strategies in infographics. Lingue e Linguaggi, 29, 291-314. https://www.doi.org/10.1285/i22390359v29p291

Rathgeb, M. (2015). Otl Aicher: Markus Rathgeb. London: Phaidon Press.

Rhiannon Gittins \& Paul Pettitt. (2017). Is Palaeolithic cave art consistent with costly signalling theory? Lascaux as a test case. World Archaeology, 49(4), 466-490, https://doi.org/10.1080/00438243.2017.1386590

Rus, H. M., \& Cameron, L. D. (2016). Health communication in social media: Message features predicting user engagement on diabetes-related Facebook pages. Annals of Behavioral Medicine, 50(5), 678-689. https://doi.org/10.1007/s12160-016-9793-9

Schiller, K., \& Young, C. (2010). Motion and landscape: Otl Aicher, Günther Grzimek and the graphic and garden designs of the 1972 Munich Olympics. Urban History, 37(02), 272288. https://doi.org/10.1017/s0963926810000350

Sharudin, S. A., Mustaffa, N., \& Sannusi, S. N. (2020). Peranan infografik dalam meningkatkan kesedaran kesihatan belia daripada perspektif pereka grafik Peranan infografik dalam meningkatkan kesedaran kesihatan belia daripada perspektif pereka grafik. Jurnal Komunikasi: Malaysian Journal of Communication, 36(1), 356-368.

Vosoughi, S., Roy, D., \& Aral, S. (2018, March 9). The spread of true and false news online. Science, 359(6380). https://www.media.mit.edu/publications/the-spread-

We Are Social. (2019). Digital 2019 Malaysia. https://wearesocial.com/global-report-2019

Yuvaraj, M. (2017). Infographics: Tools for designing, visualizing data and storytelling in libraries. Library Hi Tech News, 34(5), 6-9. https://doi.org/10.1108//htn-01-2017-0004 